\title{
Formation of environmentally friendly chloroorganic compounds technology by sewage and by-products utilization
}

\author{
Jerzy Myszkowski, Eugeniusz Milchert, Waldemar Paździoch, Robert Pełech \\ Szczecin University of Technology, Institute of Chemical Organic Technology, Pulaskiego 10, 70-322 Szczecin, Poland, \\ e-mail: Robert.Pelech@ps.pl
}

\begin{abstract}
The processes presented in the study enables the separation and disposal of the chloroorganic compounds as by-products from the vinyl chloride plant by using the dichlorethane method and also from the production of propylene oxide by the chlorohydrine method. The integrated purification method of steam stripping and adsorption onto activated carbon allows a complete removal and recovery of the chloroorganic compounds from waste water. Waste distillation fraction is formed during the production of vinyl chloride. 1,1,2trichloroethane separated from the above fraction, can be processed to vinylidene chloride and further to 1,1,1-trichloroethane. 2,3-Dichloropropene, 2-chloroallyl alcohol, 2-chloroallylamine, 2-chlorothioallyl alcohol or bis(2-chloroallylamine) can be obtained from 1,2,3-trichloropropane. In the propylene oxide plant the waste 1,2-dichloropropane is formed, which can be ammonolysed to 1,2-diaminopropane or used for the production of $\beta$-methyltaurine. Other chloroorganic compounds are subjected to chlorinolysis which results in the following compounds: perchloroethylene, tetrachloromethane, hexachloroethane, haxachlorobutadiene and hexachlorobenzene. The substitution of the milk of lime by the soda lye solution during the saponification of chlorohydrine eliminates the formation of the $\mathrm{CaCl}_{2}$ waste.
\end{abstract}

Keywords: recycling, chloroorganic compounds, vinyl chloride, propylene oxide.

Presented at VII Conference Wasteless Technologies and Waste Management in Chemical Industry and Agriculture, Międzyzdroje, 12 - 15 June, 2007.

\section{INTRODUCTION}

In the processes of the great organic synthesis next to the usable products a lot of by-products are formed. They are obtained from the system as the wastes or in the form of sewage. Those compounds in most cases are burnt or put to a destructive oxidation. Such action leads to the loss of the valuable raw materials and in the case of burning of the chloroorganic compounds to the emission of dangerous dioxins. This article presents the suggested methods of the separation and disposal of chloroorganic compounds from the sewage and wastes formed during the production of vinyl chloride by using the dichloroethane method, propylene oxide by using the chlorohydrin method and epichlorohydrin from allyl chloride.

\section{BY-PRODUCTS AND SEWAGE UTILIZATION}

\section{By-products utilization}

In order to develop new chemical technologies or to modify the existing ones, the elements of the green chemistry have been taken into consideration for many years. This way it is possible to create non-waste technologies. In the nowadays working industrial systems, even at their constant improvement, a large amount of sewage and wastes is produced. They are the processes of synthesis and the processing of the organic chloroderivatives which, for example, produce vinyl chloride by the pyrolisys of 1,2-dichloroethane obtained with the method of ethylene chlorination and oxychlorination. Waste streams of chloroderivatives constitute about $5 \%$ of the product weight and on average about $10000 \mathrm{Mg} / \mathrm{year}^{1}$. They are the distillation residues bottoms and the so-called light ends. Their main components are: 1,1,2-trichloroethane (112TCE), chloroform, tetrachloroethanes, perchloroethylene (PER), pentachloroethane ${ }^{1}$. It is possible to make their dehydrochlorination to vinylidene chloride (VDC) by the elimination of 112TCE and to obtain 1,1,1-trichloroethane (111TCE) as a result of hydrochlorination ${ }^{2,3}$. The process proceeds in accordance with the reactions presented below:

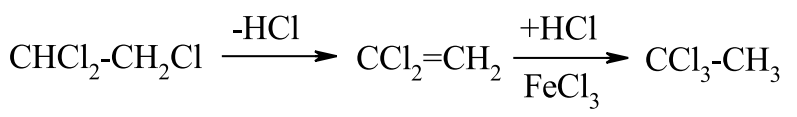

The 112TCE dehydrochlorination is carried out in the flow reactor in the aqueous solution of $\mathrm{NaOH}$. The basic technological parameters of those processes were presented in Table 1.

The directions of 123TCP processing to the usable compounds are shown in Fig.1. There is also a possibility to obtain 2-chloroallylamine and 2-chloroallyl alcohol from 2,3-dichloro-1-propene as a by-product. The optimal technological parameters of those carried out processes were presented in Table 2. The heavy distillation residue bottoms and fractional distillation residue bottoms of epichlorohydrin are the main source of obtaining 123TCP wastes. The standard composition (wt \%) is as follows: epichlorohydrin (EPI) - 7,3; 1,3-dichloropropane2-ol (13DCP2) - 1,7; 2,3-dichloropropane-1-ol (23DCP1) - 25,9; 1,2,3-trichloropropane (123TCP) - 59,5; bis(chloropropyl) ethers $-4,2$; polymeric products $-1,4$. The direction of the processing of heavy ends from the epichlohydrin distillation is shown in Fig. 2. One of the usable products received from that waste is gliceryne. It is obtained as a result of the alkaline hydrolysis of dichloropropanols and epichlorohydrin. It is possible to carry out the hydrolysis with the sodium carbonate or the mixture of carbonate and $\mathrm{NaOH}$. The conditions of the process and the basic technological quantities are presented in Table 3. 
Table 1. The technological parameters of the 1,1,2-trichloroethane (112TCE) dehydrochlorination to vinylidene chloride (VDC) and hydrochlorination of VDC to 1,1,1-trichloroethane (111TCE)

\begin{tabular}{|l|c|c|}
\hline \multicolumn{1}{|c|}{ Process } & dehydrochlorination 112TCE to VDC & $\begin{array}{c}\text { hydrochlorination } \\
\text { VDC to 111TCE }\end{array}$ \\
\hline Temperature, ${ }^{\circ} \mathrm{C}$ & $70-80$ & $20-25$ \\
\hline Molar ratio, & $\mathrm{NaOH} / 112 \mathrm{TCE}$ & $\mathrm{HCl} / \mathrm{VDC}$ \\
mol $/$ mol & $1,05-1,10$ & $\mathrm{FeCl}_{3}-0,3$ \\
\hline Concentration, $\mathrm{wt} \%$ & $\mathrm{NaOH}-10$ & 140 \\
\hline Flow rate, $\mathrm{g} /\left(\mathrm{dm}^{3} \cdot \mathrm{h}\right)$ & 270 & 0 \\
\hline
\end{tabular}

Table 2. The technological parameters of chloroallylamine, 2-chlorallyl alcohol and 2-chlorallyl thioalcohol production

\begin{tabular}{|c|c|c|c|}
\hline $\begin{array}{r}\text { Product } \\
\end{array}$ & 2-chloroallyl Alcohol & 2-Chloroallylamine & 2-chloroallyl thioalcohol \\
\hline Tempe rature, ${ }^{\circ} \mathrm{C}$ & 80 & 58 & 58 \\
\hline Time, $\mathrm{h}$ & 2,7 & 2,0 & 4,4 \\
\hline $\begin{array}{l}\text { Molar ratio, } \\
\mathrm{mol} / \mathrm{mol}\end{array}$ & $\begin{array}{c}\mathrm{NaOH} / \mathrm{DCPen} \\
20,0 \\
\end{array}$ & $\begin{array}{c}\mathrm{NH}_{3} / \mathrm{DCPen} \\
17,8 \\
\end{array}$ & $\begin{array}{c}\mathrm{NaSH} / \mathrm{DCPen} \\
2,2 \\
\end{array}$ \\
\hline Concentration, \%w. & $\mathrm{NaOH}-5,0$ & - & $\mathrm{NaSH}-26,6$ \\
\hline Conversion DCPen, \% & 100 & 100 & 97,6 \\
\hline Selectivity & 84,3 & 97,4 & 59,2 \\
\hline
\end{tabular}

DCPen = 2,3-dichloro-1-propene

Table 3. The condition of glycerol production from the epichlorohydrin distillation waste

\begin{tabular}{|l|c|}
\hline Parameter & Value \\
\hline Temperature, ${ }^{\circ} \mathrm{C}$ & 100 \\
\hline Molar ratio of the alkali to hydrolyzed chlorine, mol/mol & $1,3: 1$ \\
\hline Time, min & $105-150$ \\
\hline Glycerol yield, mol\% & $92-94$ \\
\hline Conversion of hydrolyzed chlorine & $92-98$ \\
\hline Glycerol concetration, wt\% & $20-30$ \\
\hline
\end{tabular}

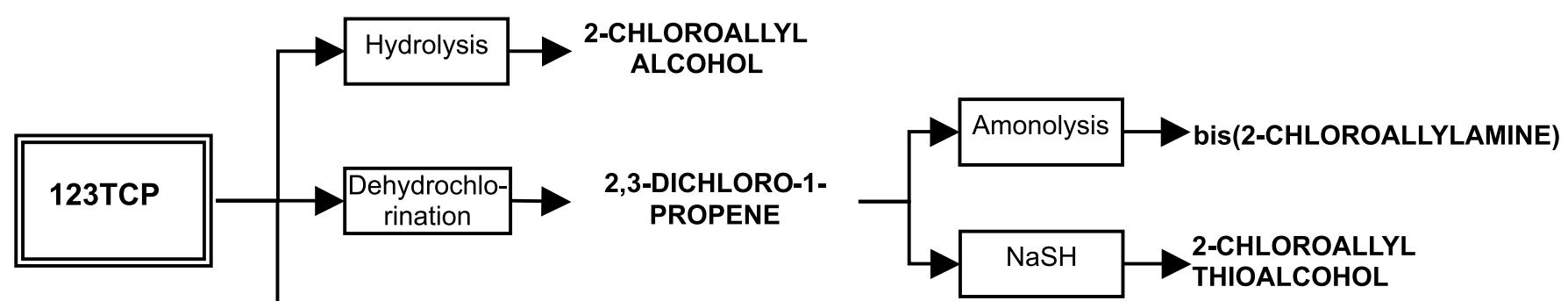

Amonolysis $\rightarrow$ 2-CHLOROALLYLAMINE

Figure 1. The directions of 1,2,3-trichloropropane processing

The chloroderivative wastes are also obtained in the systems producing the propylene oxide by chlorohydrin method. The main important ones are: 1,2dichloropropane (12DCP) $(5-7000 \mathrm{Mg} /$ year) and bis(1chloropropyl) ether ${ }^{1,4}$.

The possibilities of using the 1,2-dichloropropane usable compounds are presented in Diagram 3. The reactions proceeding in the processes are presented below:

- thionourethane synthesis

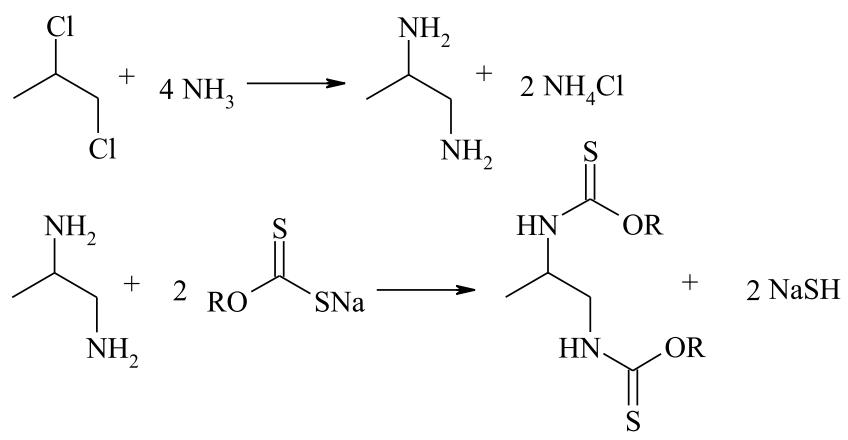

$-\beta$-methyltauryne synthesis

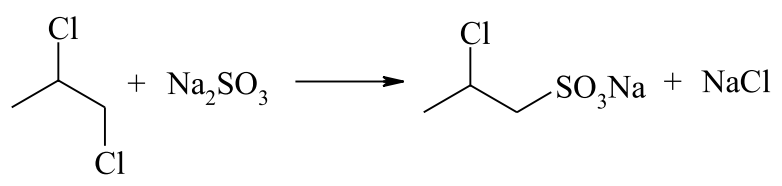

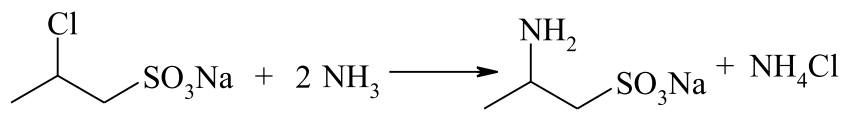

- allyl chloride synthesis

$$
\begin{aligned}
& \mathrm{CH}_{3}-\mathrm{CHCl}-\mathrm{CH}_{2} \mathrm{Cl} \stackrel{-\mathrm{HCl}}{\longrightarrow} \\
&- \text { isomerisation } \mathrm{CH}_{2}=\mathrm{CH}-\mathrm{CH}_{2} \mathrm{Cl} \\
& \mathrm{CH}_{3}-\mathrm{CHCl}-\mathrm{CH}_{2} \mathrm{Cl} \stackrel{\mathrm{AlCl}_{3}}{\longrightarrow} \mathrm{CH}_{2} \mathrm{Cl}_{-}-\mathrm{CH}_{2}-\mathrm{CH}_{2} \mathrm{Cl}
\end{aligned}
$$

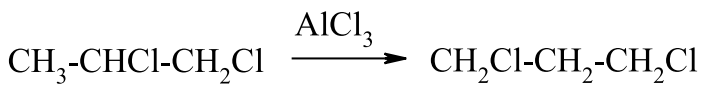

The optimal technological parameters of the 12DCP waste ammonolysis to 1,2-diaminopropane (12DAP) and polypropylenepolyamine (PPPA) were presented in Table 4.

It is possible to subject the left wastes to chlorinolysis just to obtain tetrachlomethane and PER ${ }^{5}$. In recent years the demand for tetrachloromethane has been significantly decreased because of the discontinuation of the 11,12,13 
Table 4. The optimal condition of 1,2-diaminopropane (12DAP) and polypropylenepolyamine (PPPA) production

\begin{tabular}{|l|c|c|}
\hline \multicolumn{1}{|c|}{ Product } & 12DAP & PPPA \\
\hline Temperature, ${ }^{\circ} \mathrm{C}$ & $160-170$ & $120-130$ \\
\hline Time, $\mathrm{h}$ & $3-4$ & $3-4$ \\
\hline Molar ratio $\left(\mathrm{NH}_{3} / 12 \mathrm{DCP}\right), \mathrm{mol} / \mathrm{mol}$ & $8-10$ & $2-4$ \\
\hline Emulsifier concentration, wt\% & 0,5 & - \\
\hline Selectivity 12DAP, mol\% & 74,4 & 55,0 \\
\hline Selectivity PPPA, mol\% & 22,5 & 40,0 \\
\hline Conversion of 12DCP, mol\% & 98,0 & 99,0 \\
\hline
\end{tabular}

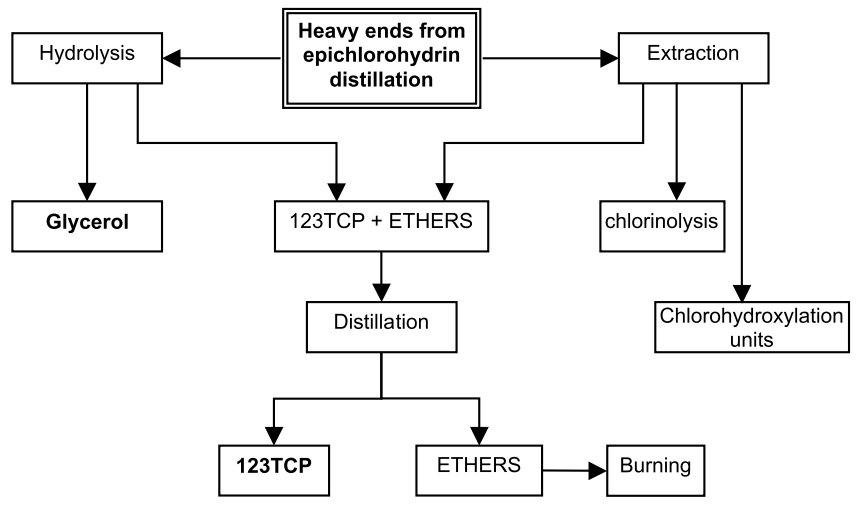

Figure 2. The directions of the heavy ends from epichlorohydrin distillation processing, 123TCP 1,2,3-trichloropropane, ETHERS - mixture of bis(chloropropyl) ethers

Freon production. Nowadays the process is carried out towards PER. During the waste chloroderivatives chlorinolysis, the secondary wastes - „hexes” are formed. They are the mixture of hexachlorobenzene (HCB), hexachlorobutadiene $(\mathrm{HCBu})$ and hexachloroethane $(\mathrm{HCE})^{\mathbf{1}, \mathbf{5}}$. It is possible to process $\mathrm{HCBu}$ to $\mathrm{HCE}$, dichloromaleate anhydride or to use as a solvent. Applying $\mathrm{HCE}$ is connected with processing it into the 113 freon or with using it as antypirene, plasticizer or the component of fungicidal and insecticidal preparations. The diagram of $\mathrm{HCB}, \mathrm{HCBu}$ and $\mathrm{HCE}$ separation from the post-reaction mixture is shown in Fig. 4. Pentachlorophenol (PCF) and sodium pentachlorophenate (PCFNa) obtained from HCB are the compounds of a great techni-

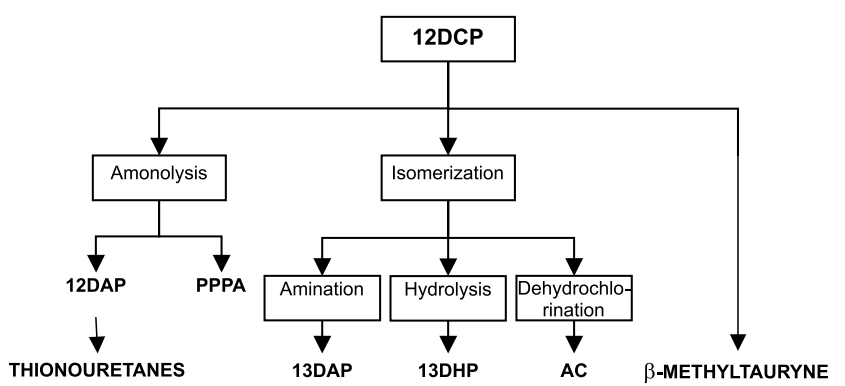

Figure 3. The directions of the waste 1,2-dichloropropane (12DCP) processing, 12DAP - 1,2diaminopropane, PPPA -polypropylenepolyamines, 13DAP - 1,3-diaminopropane, 13DHP - 1,3dihydroxypropane, CA - allyl chloride

cal matter. The HCB hydrolysis is carried out by using the sodium hydroxide in aqueous or methanol environments. The PCF synthesis is presented in Table 5 and Fig. 5 shows the diagram of the PCF production system. The HCB is mixed with the solution of sodium hydroxide in a mixer 1 and the formed suspension is forced through to the autoclave and led into direct steam heating of about $200^{\circ} \mathrm{C}$. The aqueous suspension PCFNa, HCB, sodium chloride and the excess sodium chloride flows through the condenser 3 to the phase separator 4 , where the unchanged HCB is separated. The aqueous solution is led to the batch rifining kettle and acidified to the $3-5 \mathrm{pH}$. The $\mathrm{PCF}$ is separated in the form of small crystals which are filtered off and washed with hot water to eliminate sodium chloride on filter 7 . The mother solution after the filtration and the water obtained during the washing are accumulated in container 8 , separated from the rest of the crystals and led to the sodium chloride recovery.

\section{Sewage utilization}

During the vinyl chloride production, the stream of waste water, toxic for the environment, is produced as well ${ }^{1}$. It contains chloroderivatives at about $4-5 \mathrm{~kg} / \mathrm{Mg}$ of waste water. The application of the two-stage purification may lead to its total removal ${ }^{6}$. The first stage allows the removal of the chloroderivatives to the level $5-10 \mathrm{~g} /$ $\mathrm{Mg}$ by using the method of steam stripping6 - 8. Using the fixed bed adsorption in the form of activated carbon causes the decrease of the chloroderivatives concentration
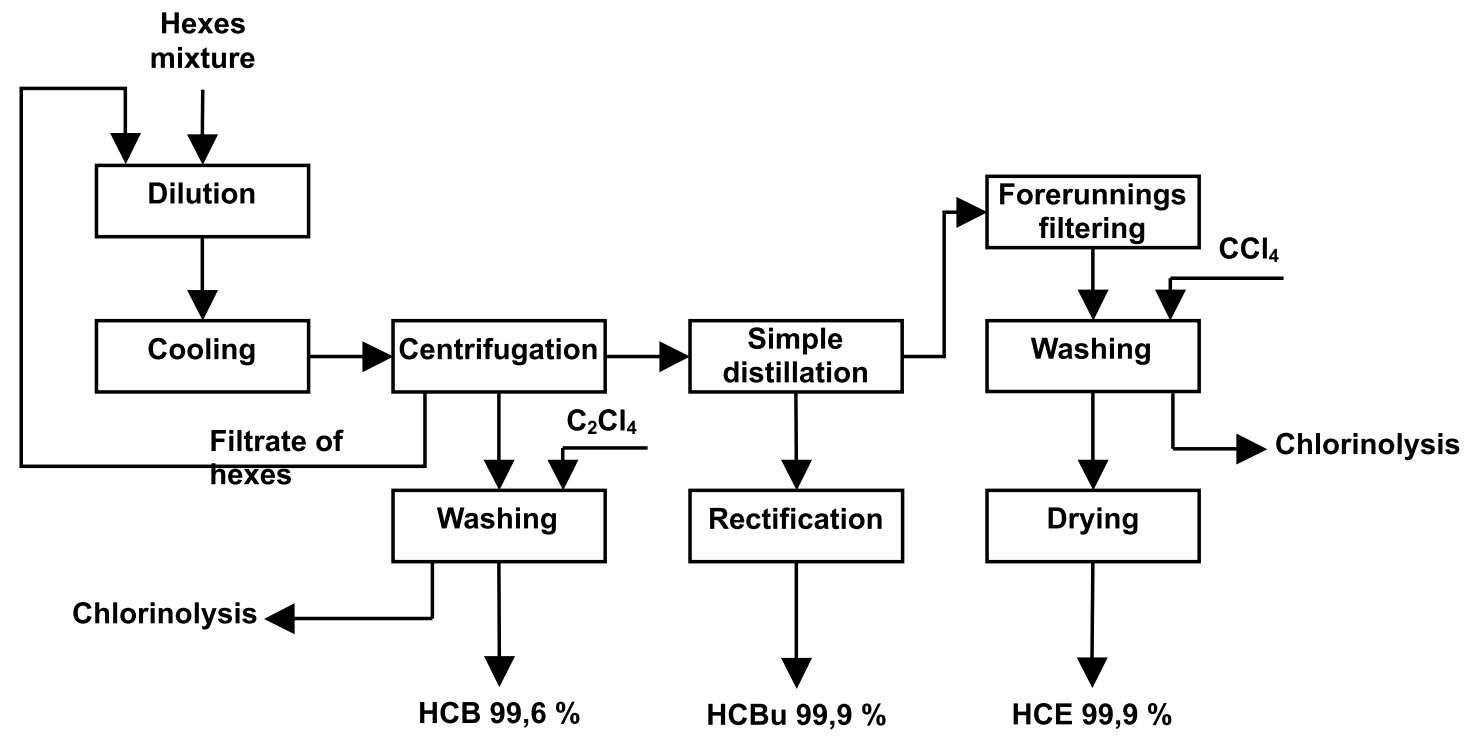

Figure 4. The diagram of the $\mathrm{HCB}, \mathrm{HCBu}$ and $\mathrm{HCE}$ separation 


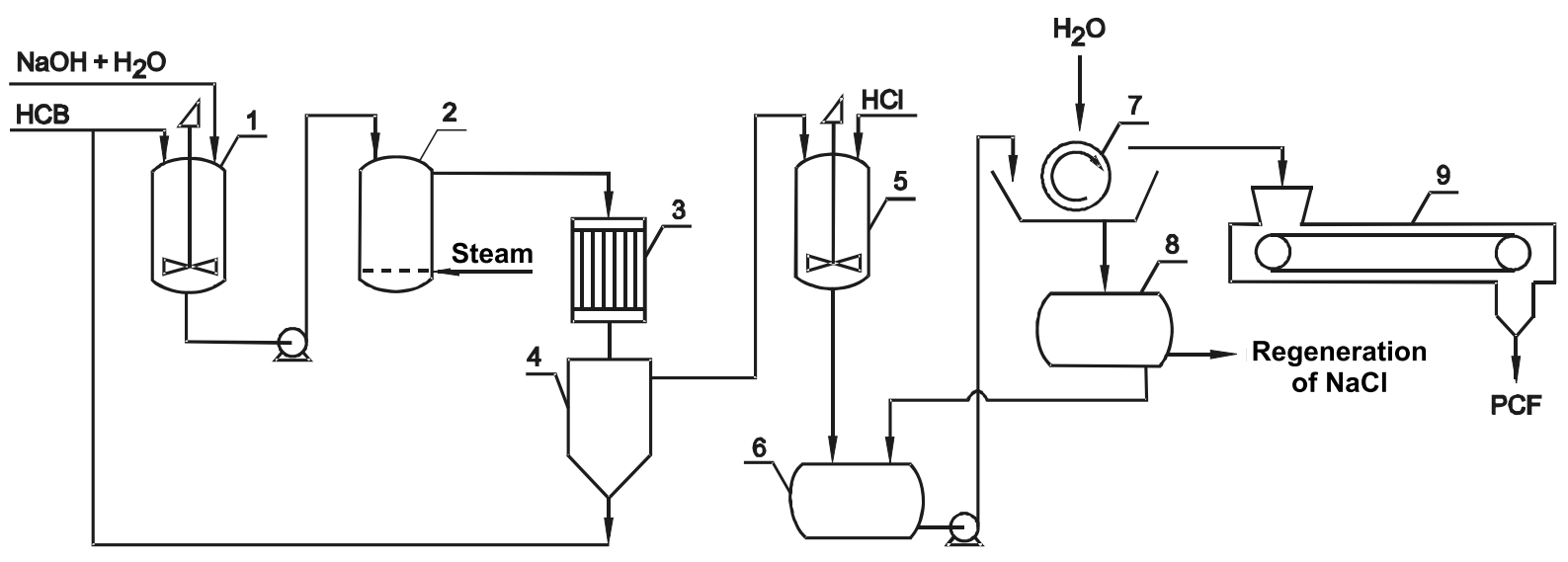

Figure 5. The PCF synthesis, 1 - agitator, 2 - reactor, 3 - cooler, 4 - separator, 5 - neutralizer, 6,8 - tanks, 7 - vacuum filter, 9 - dryer

Table 5. The condition of pentachlorophenol production

\begin{tabular}{|l|c|c|}
\hline $\begin{array}{l}\text { environment } \\
\text { Parameter }\end{array}$ & water & $\begin{array}{c}\text { methyl } \\
\text { alcohol }\end{array}$ \\
\hline Temperature, ${ }^{\circ} \mathrm{C}$ & $200-210$ & $130-150$ \\
\hline Time, $\mathrm{h}$ & \multicolumn{2}{|c|}{$1,0-1,5$} \\
\hline $\mathrm{NaOH}$ concentration, $\mathrm{wt} \%$ & $10-15$ \\
\hline $\begin{array}{l}\text { Molar ration of } \mathrm{NaOH} / \mathrm{HCB}, \\
\mathrm{mol} / \mathrm{mol}\end{array}$ & $2,5: 1,0$ \\
\hline
\end{tabular}

below $1 \mathrm{mg} / \mathrm{Mg}$. The preservative way of those operations enables to recover and then to apply the chloroderivatives in about $900 \mathrm{Mg} / \mathrm{r}^{\mathbf{9}-11}$.

The above method can be also used with the waste water obtained from the propylene oxide production ${ }^{\mathbf{1 2}, 13}$. The application of the integrated purification method of steam stripping and then adsorption onto the activated carbon allows to recover about $1920 \mathrm{Mg} / \mathrm{r}$ of the usable chloroderivatives from the waste water from the system of epichlorohydrin productivity $25000 \mathrm{Mg} / \mathrm{r}$ and about $820 \mathrm{Mg} / \mathrm{r}$ of the usable chloroderivatives from the system of propylene oxide productivity $12000 \mathrm{Mg} / \mathrm{r}^{\mathbf{1}, \mathbf{2}, \mathbf{1 4}}$.

Limitation of the waste water amount from the propylene oxide system is possible through the substitution of the milk of lime by the soda lye solution or catholyte. The produced brine is turned back to the electrolysis system after the removal of organic compounds and concentra$\operatorname{tion}^{15,16}$.

\section{CONCLUSION}

The suggested methods of the waste recycling and the waste water purification enable a recovery a large amount of chloroderivative compounds which can be used for the synthesis of valuable organic by-products and at the same time will lead to the reduction of toxic compounds emission into the environment.

\section{LITERATURE CITED}

(1) Milchert E.: Technologie produkcji chloropochodnych organicznych, utylizacja odpadów, Wydawnictwo Uczelniane Politechniki Szczecińskiej, Szczecin 1997.

(2) Milchert E., Paździoch W., Myszkowski J.: Dehydrochlorination of waste 1,1,2-trichloroethane. Ind. Eng. Chem. Res., 1995, 34, 2138 - 2141.

(3) Milchert E., Osiewicz B., Myszkowski J.: Otrzymywanie 1,1,1-trichloroetanu w wyniku chlorowodorowania chloru winylidenu. Przem. Chem., 1992, 71, 376 - 378.
(4) Bijsterbosch J., Das A., Kerkhof F.: Clean technology in the production of epichlorohyrin. J. Cleaner Prod., 1994, 2, $181-184$.

(5) Osiewicz B., Milchert E., Myszkowski J.: Chlorowanie odpadowych frakcji 1,2-dichloroetanu $\mathrm{z}$ produkcji chlorku winylu. Przem. Chem., 1993, 10, 406 - 408.

(6) Myszkowski J., Milchert E., Odzyskiwanie chloropochodnych organicznych ze ścieków w układzie stripper-adsorber. Przem. Chem., 2003, 82, 1048 - 1050.

(7) Milchert E., Goc W., Pełech R.: Adsorption of $\mathrm{CCl}_{4}$ from aqueous solution on activated carbons. Adsorpt. Sci. Technol., 2000, 18, 823 - 837.

(8) Pełech R., Bembnowska A., Milchert E.: Adsorption of hydrocarbon chloro-derivatives onto DTO commercial activated carbon from multi-component aqueous solutions. Adsorpt. Sci. Technol., 2003, 21, $707-720$.

(9) Pełech R., Milchert E., Bartkowiak M.: Fixed-bed adsorption of chlorinated hydrocarbons from multicomponent aqueous solution onto activated carbon: equilibrium column model. J. Colloid Interf. Sci., 2006, 296, 458 - 464.

(10) Pełech R., Milchert E., Wróblewska A.: Desorption of chloroorganic compounds from a bed of activated carbon. J. Colloid Interf. Sci., 2005, 285, 518 - 524.

(11) Pełech R., Milchert E.: Zastosowanie węgla aktywnego do usuwania chloropochodnych organicznych ze ścieków. Wydawnictwo Pracowni Adsorpcji i Katalizy w Ochronie Środowiska Wydział Chemii, UAM, Poznań 2004, 113.

(12) Bembnowska A., Pełech R., Milchert E.: Adsorption from aqueous solutions of chlorinated organic compounds onto activated carbons. J. Colloid Interf. Sci., 2003, 256, 276 -282 .

(13) Milchert E., Goc W., Myszkowski J.: Recovery of epichlorohydrin and dichloropropranols from waste. J. Chem. Technol. Biotechnol., 1993, 56, 109 - 111.

(14) Myszkowski J., Milchert E.: Recovery of chloroorganic compounds from waste waters of glycerine epichlorohydrin production. Pol. J. Chem. Technol., 2001, 3, 17 - 19.

(15) Milchert E., Goc W., Meissner E., Myszkowski J.: Dehydrochlorination of propylene chlorohydrin with sodiumhydroxide and with catholyte. J. Chem. Technol. Biotechnol., 1994, 61, 251 - 254.

(16) Milchert E., Myszkowski J., Bezściekowa chlorohydrynowa metoda produkcji tlenku propylenu zintegrowana z elektrolizą solanki. Chemik, 1993, 46, 3 - 6 . 